\title{
Belgeo
}

Revue belge de géographie

\section{Characterising rainfall regimes in relation to recharge of the Sierra de Gador-Campo de Dalias aquifer system (S-E Spain)}

Caractérisation des précipitations en fonction de la recharge de l'aquifère de

Sierra de Sador-Campo de Dalias (s.e. Espagne)

Elisabeth Frot, Bas van Wesemael, Grégoire Vandenschrick, Roland Souchez and Albert Solé Benet

\section{OpenEdition}

Electronic version

URL: http://journals.openedition.org/belgeo/16055

DOI: 10.4000/belgeo.16055

ISSN: 2294-9135

Publisher:

National Committee of Geography of Belgium, Société Royale Belge de Géographie

Printed version

Date of publication: 30 June 2002

Number of pages: $145-158$

ISSN: 1377-2368

Electronic reference

Elisabeth Frot, Bas van Wesemael, Grégoire Vandenschrick, Roland Souchez and Albert Solé Benet, « Characterising rainfall regimes in relation to recharge of the Sierra de Gador-Campo de Dalias aquifer system (S-E Spain) », Belgeo [Online], 2 | 2002, Online since 01 July 2002, connection on 19 April 2019. URL : http://journals.openedition.org/belgeo/16055; DOI : 10.4000/belgeo.16055

This text was automatically generated on 19 April 2019.

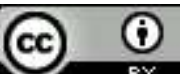

Belgeo est mis à disposition selon les termes de la licence Creative Commons Attribution 4.0 International. 


\title{
Characterising rainfall regimes in relation to recharge of the Sierra de Gador-Campo de Dalias aquifer system (S-E Spain)
}

\author{
Caractérisation des précipitations en fonction de la recharge de l'aquifère de \\ Sierra de Sador-Campo de Dalias (s.e. Espagne)
}

\author{
Elisabeth Frot, Bas van Wesemael, Grégoire Vandenschrick, Roland \\ Souchez and Albert Solé Benet
}

The pressure on water resources around the Mediterranean basin is growing at an alarming rate as a result of increases in water demand from agriculture, tourism and industry. The Campo de Dalias (Almeria province, south-east Spain) is a prime example of an area where the aquifers are overexploited. Early season horticulture for the European market has expanded rapidly since the 1960s. Greenhouses now cover an area of 20000 ha in the Campo de Dalias and annual water use at $100 \mathrm{hm}^{3}$ largely exceeds estimated recharge at $50 \mathrm{hm}^{3}$ (Tout, 1990; Pulido Bosch et al., 1993). Although the aquifer volume is very large, the risk of marine intrusions is becoming real since in some areas the piezometric level has fallen to $20 \mathrm{~m}$ below sea level (Pulido Bosch, 1993). The complexity and the scale of the Campo de Dalias aquifer and the carbonatic mountain range of the Sierra de Gador are such that several authors have used stable water isotopes ( $\delta \mathrm{D}$ and $\delta^{18}$ o) in order to understand the recharge of the aquifers. Stable isotope studies of precipitation and groundwater in the Mediterranean are common. However, studies focusing on the western Mediterranean are scarce (Cruz-San Julian et al., 1992; Vallejos et al., 1997; Maliki et al., 2000, Celle-Jeanton et al., 2001a, b; Vandenschrick et al., 2002). Vandenschrick et al. (2002) demonstrated that within this karstic aquifer system water with different isotopic signatures can co-exist. They explained this by assuming discontinuity of groundwater flow during moderate rainfall reaching only the perched shallow groundwater. Extreme events would then supply the main aquifer. This theory is 
underpinned by the existence of Atlantic and Mediterranean weather systems resulting in a clear distinction in isotopic signatures of the precipitation produced by these weather systems in the western part of the Mediterranean basin (Celle-Jeanton et al., 2001a; Lazaro et al., 2001). These isotopic studies directly link the isotopic signature of the precipitation to the prevailing weather conditions during the event. The balance between annual precipitation depths for Atlantic and Mediterranean is then used to determine the dominant origin of the aquifer recharge. Most studies agree on the dominance of precipitation from Mediterranean origin. This precipitation is often linked with large convective storms with a low return period locally referred to as "gotas frias» (AlonsoSarria et al., 2002). However, many low intensity rainfall events also have a Mediterranean origin (e.g. Cruz-San Julian et al., 1992) and, therefore, no information on the rainfall characteristics of individual events that favour recharge can be obtained.

the case of the Sierra de Gador-Campo de Dalias aquifer system, the large storms are known to cause flooding in the Campo de Dalias. Therefore, a network of 165 checkdams was established within the ephemeral streams (Pulido Bosch et al., 1993). These dams increase the infiltration in particular during large events, since it is known that in arid and semi-arid areas runoff generated by moderate events does not reach ephemeral streams (Yair and Lavee, 1985; Puigdefabregas et al., 1999). One of the challenges is to increase recharge from events with a low return period yielding low and intermediate quantities per event, but forming the bulk of the annual precipitation. Water harvesting techniques concentrate water availble for infiltration by collecting the runoff of larger areas with low infiltration capacity. Lavee et al. (1997) and van Wesemael et al. (1998) have shown that the efficiency of such techniques depends largely on the surface characteristics of the catchment area and that generally infiltration losses increase with the catchment area. In analogy with traditional water harvesting techniques, runoff generated on patches of the hillslopes could therefore be concentrated using small dams and channels on the hillslopes where runoff occurs most frequently.

The objective of this paper is to investigate whether moderate precipitation events play a role in aquifer recharge. Once we have singled out a parameter from the isotopic signature that distinguishes between the two source regions of the water vapour (i.e. Mediterranean or Atlantic), we will search for an effect of precipitation quantity on weighted averages of isotopic signatures in precipitation samples in the Mediterranean. We will then compare the isotopic signals from precipitation, local runoff, shallow and deep groundwater in the Sierra de Gador - Campo de Dalias aquifer system in order to create a typology of the precipitation events which provoked the recharge of the groundwater.

\section{Study area}

4 The Sierra de Gador is a mountain range directly to the west of the town of Almeria (south-east Spain (Fig. 1)). It reaches $2242 \mathrm{~m}$ asl and consists of a thick series of Triassic carbonate rocks, mainly dolomites, underlain by impermeable metapelites of Permian age. The Sierra de Gador is part of the Betic orogenetic system and is connected through a zone of extensive fault systems to the coastal plains of the Campo de Dalias. 
Figure 1. Landsat image (April 2000) of the study area.

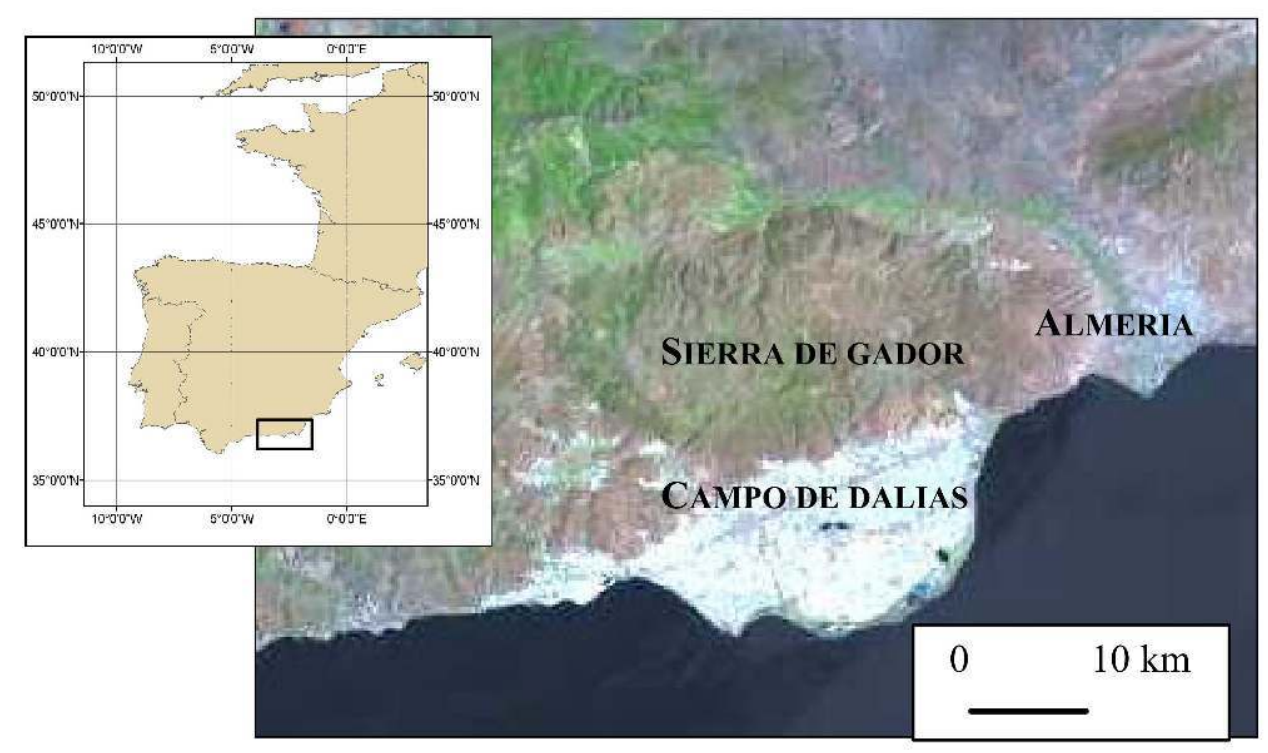

NOTE THE WHITE REFLECTANCE OF THE gREENHOUSES IN THE CAMPO DE DALIAS.

Southeast Spain is situated in the transition between the zone of influence of Altantic and Mediteranean circulation. Alonso-Sarria et al. (2002) explain the distinct origins of rainfall events over the Iberian coast as a result of variations in global atmospheric circulation modified by local topographic factors. Due to its latitude, the Mediterranean basin receives precipitation generated by frontal depressions coming from the western Altantic, convective rainfall events associated with eastern flows and cyclogenetic processes generated in the Mediterranean basin itself (Celle-Jeanton et al., 2001a). This climate is marked by a high intra and inter annual variability. The annual precipitation distribution is clearly seasonal due to the seasonal motion of the atmospheric circulation centres. During the warmer part of the year, generally from May to September, the region is under the influence of relatively high pressure which inhibits precipitation in the area. During the cooler months between October and April, surface pressure is generally reduced, allowing more frequent incursions of precipitation-producing weather systems. The months of July and August are almost completely dry, but the period OctoberFebruary is wet due to incursions of active Atlantic frontal systems (Summer et al., 2000). Extensive thunderstorm development during September and October produces an autumn peak in precipitation (Summer, et al., 2000). Almeria is characterised by the lowest annual average precipitation with a single distinct autumn precipitation maximum in October, lower mean values in July and August, and generally uniform amounts between December and May (Summer et al., 2000). Esteban-Parra et al. (1998) give an average annual precipitation of $210 \mathrm{~mm}$ for the period from 1911 to 1991.

\section{Methods}

\section{Stable water isotopes}

6 The Global Network for Isotopes in Precipitation (GNIP) provides a world-wide survey of the isotopic composition of monthly precipitation. It was created in 1961 by the 
International Atomic Energy Agency in co-operation with the World Meteorological Organisation (IAEA/WMO, 2001). We used the ${ }^{18} \mathrm{O}$ and D data for 34 stations around the Mediterranean basin and calculated the deuterium-excess $(\mathrm{d})$ values. Deuterium excess is the independent term of the equation $\delta \mathrm{D}=8 \delta^{18} \mathrm{O}+\mathrm{d}$ corresponding to what is referred to as the Meteoric Water Line. If evaporation rates are high, because of high temperature and low relative humidity in the atmosphere during the formation of the water vapour, there is a strong kinetic isotopic effect, and d becomes higher (Jouzel and Merlivat, 1984). All isotope concentrations are given hereafter in d-units calculated with respect to VSMOW (Vienna Standard Mean Ocean Water) expressed in part per mil (eq. 1)

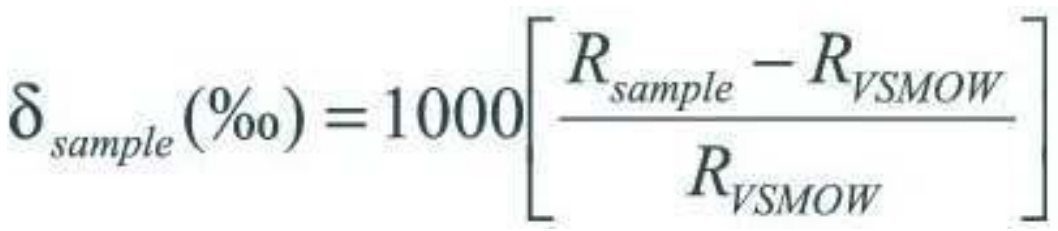

7 where $R_{\text {sample }}$ and $R_{\text {VSMow }}$ are the isotopic ratios of the sample and of the VSMOW respectively.

Water samples were collected by Cruz-San Julian et al. (1992), Vallejos et al. (1997) and Vandenschrick et al. (2002) for co-isotopic studies in the Sierra de Gador, on its lower southern slopes and in the coastal plain of the Campo de Dalias (Fig. 1). Precipitation samples were taken in April 1990 along an altitudinal gradient and five samples of snow were collected in January 2000. Samples from closed runoff reservoirs along a gradient from 550 to $1990 \mathrm{~m}$ asl date from October 1999. Shallow groundwater was sampled in October 1999 and January 2001 from six springs on the contact between the carbonate rocks and the metapelites between 400 and $970 \mathrm{~m}$ asl. Deep groundwater consists of eleven samples from irrigation boreholes, collected in October 1999. The latter are all located between 70 and $343 \mathrm{~m}$ asl in the Campo de Dalias and in the Sierra piedmont. These boreholes reach into the Triassic carbonate aquifer at depths ranging from $200 \mathrm{~m}$ at the Sierra piedmont to $900 \mathrm{~m}$ in the central zone of the Campo de Dalias. Six boreholes on the fringe of the Sierra de Gador and the Campo de Dalias were sampled at monthly intervals between 1991 and 1993 (Vallejos et al., 1997). From the continuous monitoring of the water level in three closed runoff reservoirs and pluviograph records, we were able to identify the rain events which had contributed significantly to the runoff sampled. The meteorological conditions during these rainfalls were reconstructed from weather maps provided by Météo-France. These runoff reservoirs, locally referred to as «aljibes», were constructed to provide drinking water for grazing sheep and goats. They collect runoff from hillslopes which are connected to the reservoirs by small channels.

\section{Modelling the deuterium excess of precipitation samples}

Deuterium excess is usually considered as a more or less conservative property in the part of the atmospheric water cycle beginning with water vapour formation by evaporation to rainfall just below cloud level (Ciais and Jouzel, 1994). In order to quantify the relation between the deuterium excess parameter and the conditions during the evaporation of the water vapour leading to precipitation, Vandenschrick (2002) developed a two-dimensional model representing the isotopic fractionation during the phase changes that the water vapour undergoes on its trajectory (Fig. 2). Only the outlines of the model are given below. The model simulates the isotopic concentration 
with each of the phases in an air mass under the prevailing pressure, relative humidity, temperature and altitude. The model combines equations from the Rayleigh Model Kinetic (RMK; Jouzel \& Merlivat, 1984), the model of Johnsen et al., 1989, and the mixed cloud isotopic model (MCIM ; Ciais \& Jouzel, 1994). The model goes through four stages to describe the trajectory from the evaporation of water vapour until the precipitation. The first stage represents the initial conditions of the evaporation at the surface of the ocean under temperature (T_0) and relative humidity (Rh_0). The second stage is based on the RMK in cloud with a vapour and a liquid phase, when condensation starts at dew point (dp). The third stage consists of the interactions between vapour, liquid and solid phase modelled by the MCIM. The solid phase appears in the cloud at temperature Tg. At temperature $\mathrm{Tl}$ the liquid phase disappears from the cloud as precipitation. This is the last stage of the model, which is based on the Rayleigh model. The model finally arrives at altitude Hs at which the isotopic composition of the final precipitation is modelled. We use an inverse modelling approach to reconstruct the source conditions of a precipitation sample with known $\delta \mathrm{D}$ and $\delta^{18} \mathrm{O}$. Sensitivity analysis of the model has shown that for a given event the deuterium excess parameter is determined by the conditions at the origin of the water vapour (Rh_0 and T_0). The combination of Rh_0 and $T_{-} 0$ at the sea surface during the months with the highest evaporation rates enables us to reconstruct the source area of the water vapour.

Figure 2. Illustration of the model explaining the isotope concentrations in precipitation (סD_p; $\delta^{18}$ O_p; d_p) as a function of the trajectory of air masses from evaporation at the sea surface at prevailing relative humidity and temperature $\left(\mathrm{Rh} \_0 ; T_{-} 0\right)$ to its precipitation above the land surface (shaded area) at height (Hs).

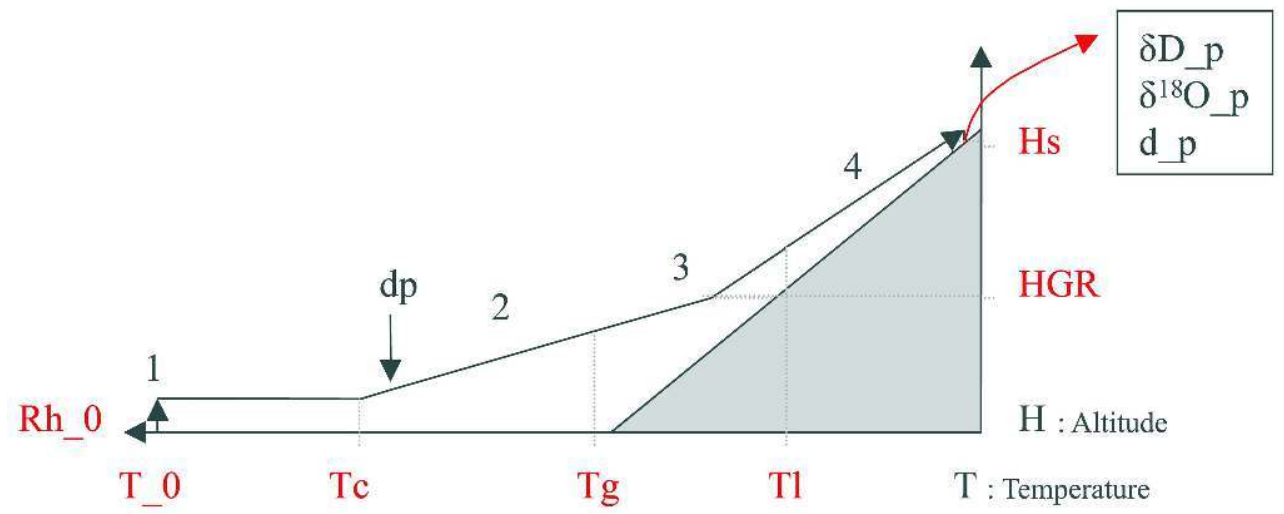

WHERE DP: DEW POINT, TC: TEMPERATURE AT THE START OF THE RISINg OF THE AIR MASSES, Tg: TEMPERATURE AT THE APPEARANCE OF ICE IN THE AIR MASSES; TL: TEMPERATURE AT THE DISAPPEARANCE OF WATER FROM THE AIR MASSES; HGR: ALTITUDE OF THE AIR MASSES AT THE END OF RADIATIVE COOLINg.

\section{Results and discussion}

\section{Deuterium excess as a parameter to reconstruct the origin of precipitation in the western Mediterranean}

10 The isotopic signature of precipitation and runoff samples collected in the Sierra de Gador are given in Figure 3. The weather maps of Figure 4 illustrate the general north western circulation bringing frontal rainfall from the Atlantic in October 1999. The 
runoff, generated on hillslopes ranging from 0.3 to 7.8 ha was sampled a few days later from 11 closed runoff reservoirs. Vandenschrick et al. (2002) have analysed the water level and pluviograph records of three of these reservoirs. They argue that significant quantities of runoff are produced during a limited number of events with weather conditions similar to the ones in October 1999. The rainfall of April 1990 was sampled by Cruz-San Julian et al. (1992). These authors stated that the clouds arriving from the south west lost their rainfall over the Atlas mountains and picked up water vapour from the western Mediterranean before producing rainfall on the Sierra de Gador. While the $\delta \mathrm{D}$ values of both types of rainfall show a large variation, the d-excess is clearly different. A mean value of $16.55 \%$ o (std $=2.77)$ can be distinguished for the Mediterranean type rainfall and the Atlantic event has a mean value of $10.23 \%$ o (std $=2.0)$. Such $d$-excess values are in agreement with those reported in the literature. Araguas-Araguas et al. (2000) state that the Mediterranean Sea is a classic example of a reservoir producing water vapour characterized by high deuterium excess. The d-excess value for the Eastern part of Mediterranean basin is known to be around 22\%o (Gat and Carmi, 1970). Whereas a $\mathrm{d}$-excess value of $10 \%$ corresponds to an Atlantic signature. The Western Mediterranean d-excess value falls between the Atlantic and the Eastern Mediterranean at around 15\%o (Celle-Jeanton et al., 2001a).

Figure 3. Isotopic characteristics of precipitation and runoff sampled along an altitudinal gradient in the Sierra de Gador.

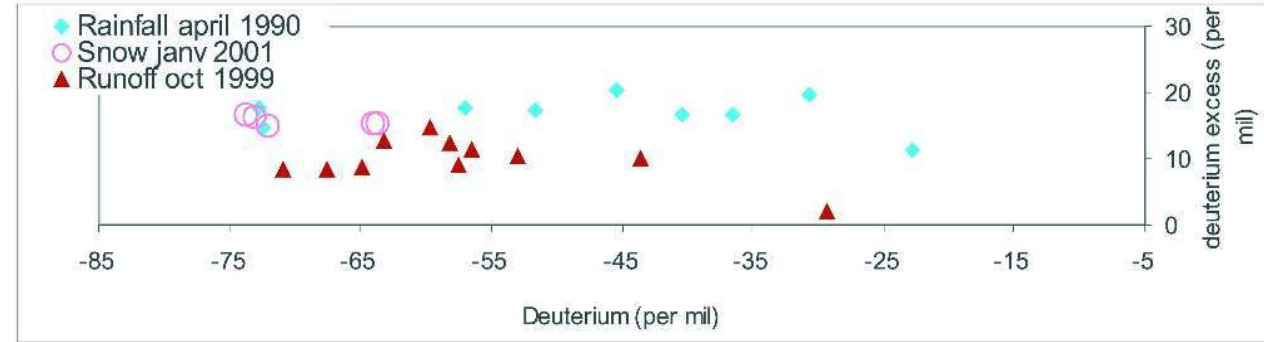

Deuterium $(\delta \mathrm{D})$ concentrations, expressed in delta units with respect to the Vienna standard mean ocean water, are plotted versus deuterium excess (d) 
Figure 4. Relative humidity and temperature at the sea surface during evaporation of the air masses at the origin of the precipitation ( $\mathrm{Rh} 0$ and $\mathrm{T} 0$ ) calculated by the isotopic model for precipitation, and runoff samples are confronted with weather maps of these events.

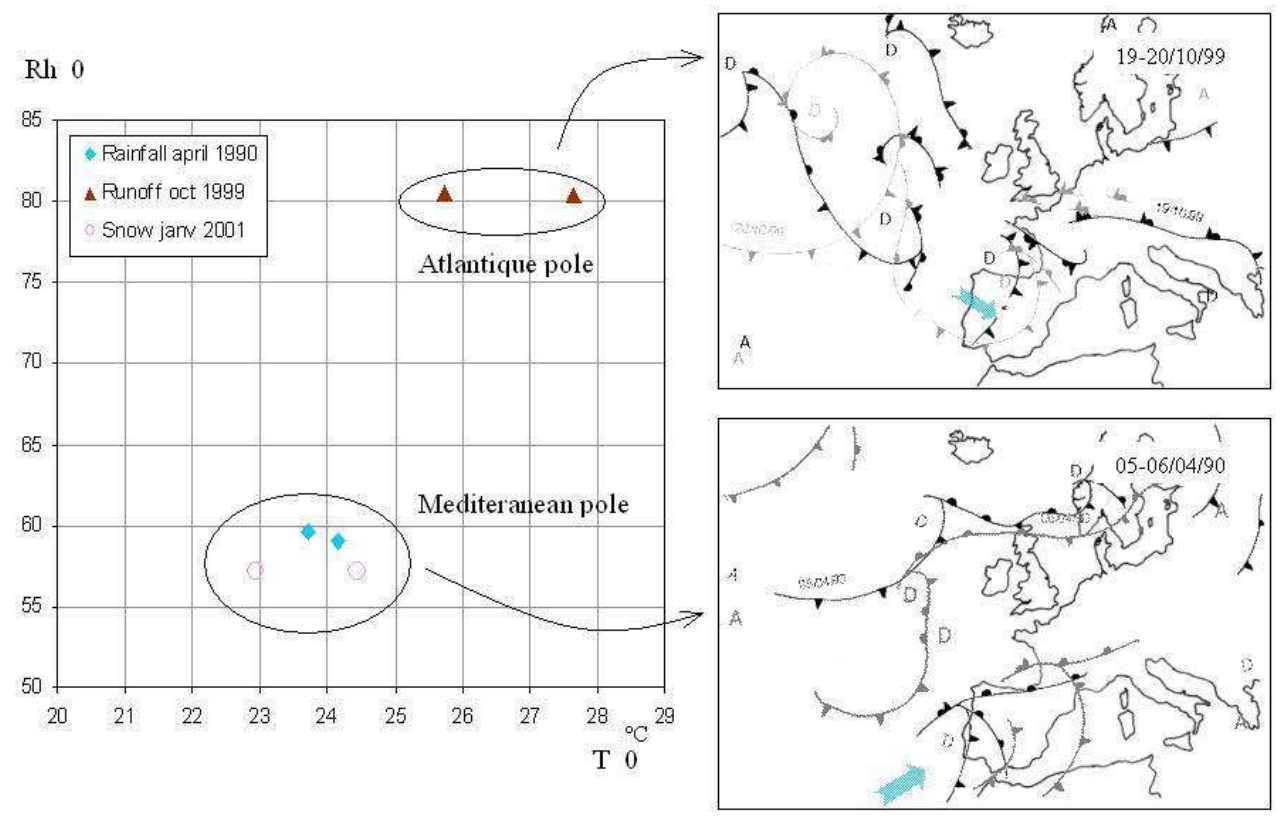

The weather maps were provided by Météo France and Cruz-San Julian et al., 1992

The extremes of the $\delta \mathrm{D}$ and $\delta^{18} \mathrm{O}$ values of the three events represented in Fig. 3 are now introduced in the isotopic model described by Vandenschrick (2002) in order to obtain the temperature ( $\mathrm{T}_{-} 0$ ) and relative humidity $(\mathrm{Rh}-0)$ at the origin of the water vapour. The results of the modelling exercise are shown in Fig. 4. Two distinct poles appear: one with a high temperature and relative humidity which contains the Atlantic precipitation and another at lower temperature and relative humidity containing the Mediterranean events. These conditions, obtained independently by the isotopic model, reflect the warm and moist conditions at the Atlantic Ocean surface in the subtropics, known as a source area for western frontal depressions and the dryer and relatively cooler conditions prevailing over the Mediterranean. Hence, the d-excess value will be used from now on as a parameter determining the origin of precipitation. This will allow us to evaluate isotopic signatures of precipitation and groundwater in those cases where it is impossible to reconstruct the prevailing weather patterns.

\section{Using deuterium excess to characterise the origin of dominant precipitation in the Mediterranean basin}

The GNIP network provides monthly isotope concentrations in precipitation together with monthly precipitation totals. These data were used to calculate mean deuterium excess values weighted by precipitation depth for each month (Fig. 5; data extracted from IAEA/WMO, 2001). An increase in d-excess values from around $10 \%$ in the western part to more than $20 \%$ at the eastern extremities of the Mediterranean basin. The mixing zone in the western part of the Mediterranean basin with d-excess values of around $15 \%$, as reported by Gat and Carmi (1970) and Celle-Jeanton et al. (2001a), can easily be distinguished. Gibraltar is a typical example of a station in the western part of the 
Mediterranean receiving both precipitation from Atlantic and western Mediterranean origin. The frequency distribution of d-excess of the monthly precipitation samples collected from 1961 until 1998 in Gibraltar is given in Fig. 6. There is no clear tendency in the number of month dominated by Atlantic and Mediterranean precipitation, since the dominant d-excess classes are those between 8 and 16\%o (Fig. 6b). However, a different picture arises from the total precipitation according to origin (Fig. 6 a). Although the weigthed mean d-excess value is still between the Atlantic and Mediterranean poles $(\mathrm{d}=12.39)$, the class with western Mediterranean and a d-excess between 12 and 16\%o increases. Furthermore, the precipitation received in the months with a clear Mediterranean signal (d-excess from 16-20\%o) forms an important contribution to the weighted mean of the d-excess in precipitation. A more clear dominance of Mediterranean type precipitation was found in southern France (Celle-Jeanton et al., 2001 a) and in Tunisia (Celle-Jeanton et al., 2001b).

Figure 5. Weighted annual mean deuterium excess in monthly precipitation samples from stations monitored by the GNIP network around the Mediterranean basin.

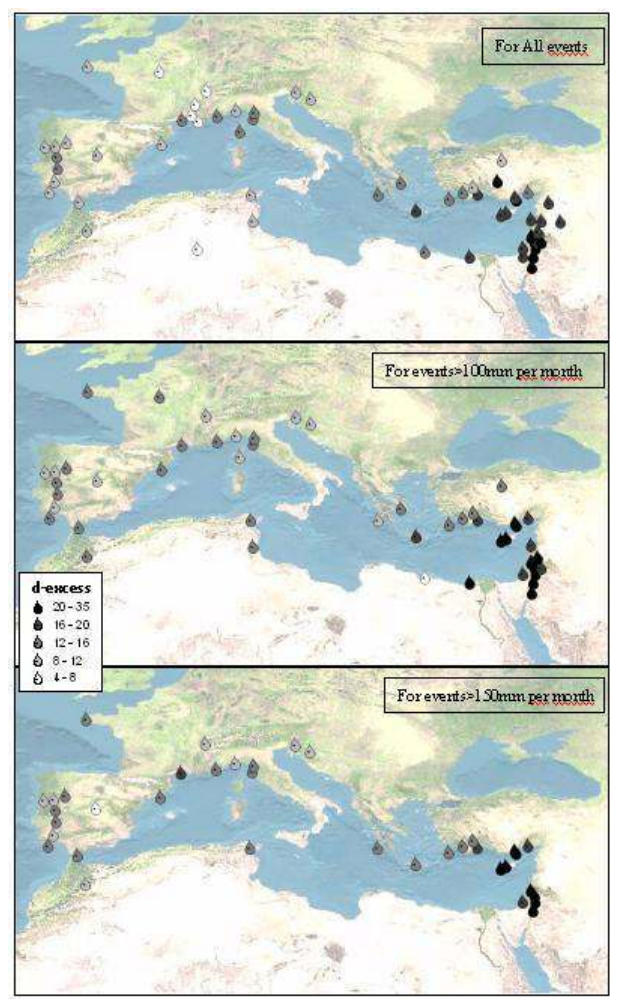

THE SHADING OF THE DROPLETS REFERS TO THE DEUTERIUM EXCESS FROM LIGHT TO DARK: 4-8; 8-12; 12-16; 16-20; 20-35

DATA EXTRACTED FROM IAEA/WMO (2001)

Figure 6. Frequency of deuterium excess values in monthly precipitation samples from Gibraltar (1962-1995) expressed in monthly rainfall depth (a) and number of month (b). 

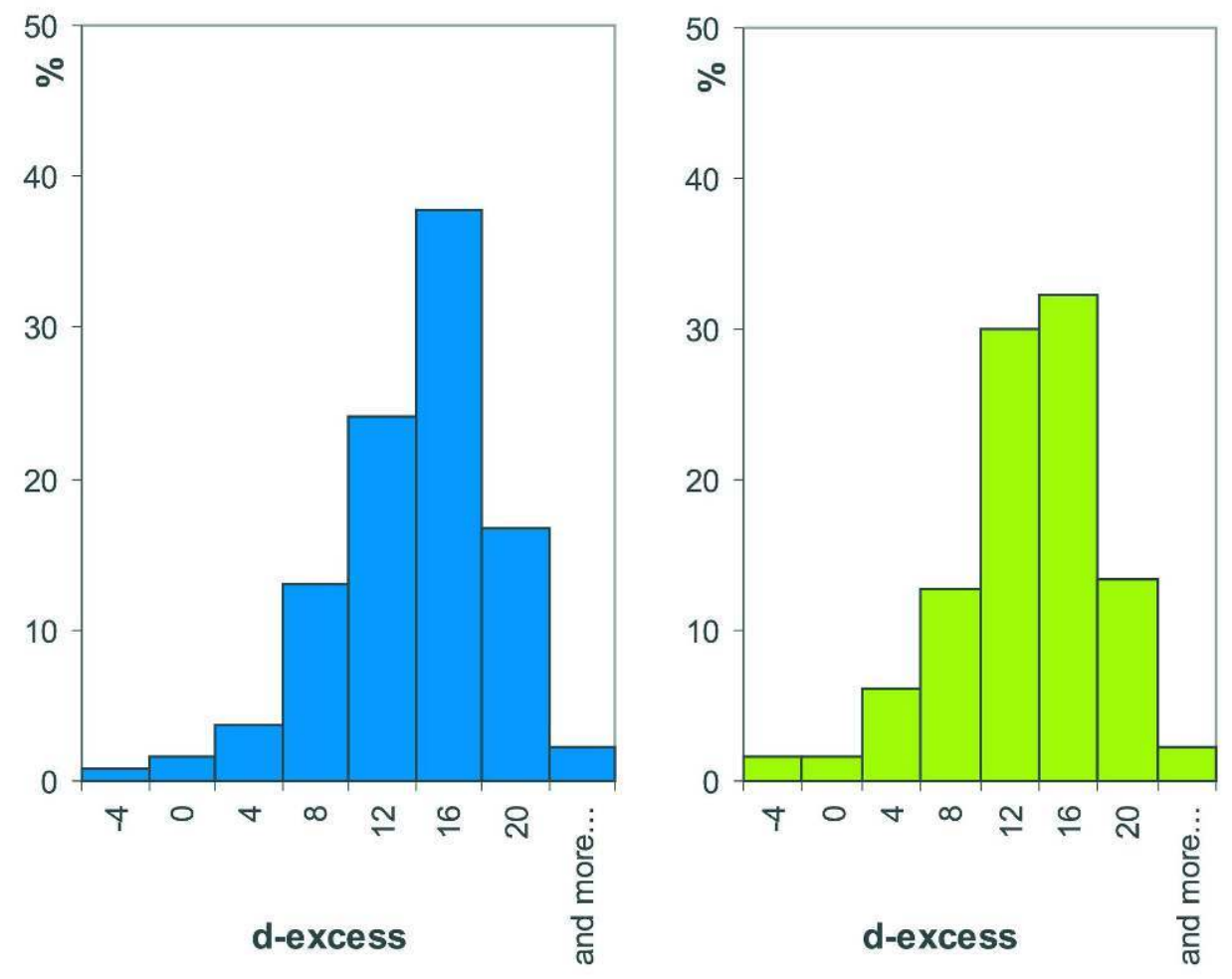

DATA EXTRACTED FROM IAEA/WMO (2001)

The Mediterranean origin of extreme events has been demonstrated (e.g. Alonso Sarria et al., 2002). However, their return period is higher than 10 years, and therefore it is worthwhile investigating whether the influence of such rare events determines the weighted average of $d$-excess values of precipitation samples in the wetter months. This hypothesis was tested on the monthly GNIP data (Fig. 5) for stations around the Mediterranean basin. Due to the rarity of extreme events and the limited records of some stations, thresholds of monthly precipitation of 100 and $150 \mathrm{~mm}$ were selected. The effect of such thresholds is most conspicuous in the western Mediterranean basin. Nearly all stations in the western Mediterranean are characterised by d-excess values between 12 and $16 \%$ when only the months with precipitation depth exceeding $150 \mathrm{~mm}$ are considered. A comparison with the map showing the d-excess of all samples illustrates a tendency towards a Mediterranean character for the heavier storms.

\section{A typology of the precipitation determining the composition of groundwater}

14 We have established that the d-excess parameter represents the origin of precipitation samples. We can now tentatively compare these to groundwater values in order to determine the typology of the precipitation events which resulted in recharge. Although we do realize that other processes such as evaporation during percolation are not taken into account by the model, groundwater bodies are a weighted average of thousands of events over a long period of time. Therefore, it is not feasible to retrace the prevailing weather conditions for all of these events, and the use of the d-excess parameter is the only option. In general aquifers in the Mediterranean basin have a d-excess value of more 
than $15 \%$ (Table 1). Lower d-excess values are often explained by the mixing of modern recharge with fossil groundwaters which were formed under different climatic conditions (e.g. Tantawi et al., 1998).

Table 1. Deuterium excess values of groundwater around the Mediterranean extracted from the literature.

\begin{tabular}{|c|c|c|c|c|}
\hline Site & Aquifer type & $\begin{array}{l}\text { d-excess } \\
\text { value }\end{array}$ & Comments & reference \\
\hline Turkey & Karst aquifer & 16.89 & $\begin{array}{l}\text { Mix between new and old } \\
\text { water. }\end{array}$ & Nativ et al. (1998) \\
\hline Egypt & $\begin{array}{l}\text { Crystalline rocks and } \\
\text { alluvial sediments }\end{array}$ & 12.69 & $\begin{array}{l}\text { Derived from local rainfall. } \\
\text { some contribution from paleo- } \\
\text { water }\end{array}$ & Tantawi et al. (1998) \\
\hline $\begin{array}{l}\text { Northern } \\
\text { Jordan }\end{array}$ & Limestone & 20.20 & $\begin{array}{l}\text { thermal and non-thermal } \\
\text { groundwater }\end{array}$ & Bajjali et al. (1996) \\
\hline Greece & carbonate rocks & 13.83 & $\begin{array}{l}\text { river water contributions, } \\
\text { relation between two marbles } \\
\text { series }\end{array}$ & Leontiadis et al. (1995) \\
\hline $\begin{array}{l}\text { Greece } \\
\text { (Nisyros } \\
\text { island) }\end{array}$ & $\begin{array}{l}\text { Hydro thermal aquifer } \\
\text { beneath the volcanic } \\
\text { crater }\end{array}$ & 14.70 & $\begin{array}{l}\text { average for } d \text {-excess values } \\
\text { without mixing process }\end{array}$ & Kavouridis et al. (1998) \\
\hline
\end{tabular}

* MEAN; ** STANDARD DEVIATION IN ITALICS AND NUMBER OF SAMPLES IN BRACKETS

Deep groundwater within the Campo de Dalias has a d-excess value ranging from $12.48 \%$ to $13.79 \%$, while the mean d-excess values of shallow groundwater in the Sierra de Gador are lower at $12.50 \%$ (Table 2). This difference can be explained by the percolation of moderate Atlantic events in 1999 and 2000 producing runoff with a mean d-excess value of $10.23 \%$ into the perched water tables in the Sierra de Gador. The very large aquifers in the Campo de Dalias are dominated by Mediterranean recharge and their d-excess value is higher than the weighted mean value of monthly precipitation in Gibraltar ( $\mathrm{d}$-excess = $12.34 \%$ ). As we have shown earlier, the heavier storms are dominantly Mediterranean and it is those storms which are mainly responsible for the recharge of the aquifers. This does, however, mean that a large part of the annual precipitation does not contribute to recharge of the aquifers. Optimizing the deep percolation of runoff from moderate events could be an option for increasing recharge. As many authors have pointed out (e.g. Yair and Lavee, 1985; Puigdefabregas et al., 1999) runoff is discontinuous and tends to be lost towards the valleybottoms. Therefore, measures to improve recharge from moderate storms need to target those parts of the hillslopes with high runoff potential such as rock outcrops and shallow soils. The decline of these areas through reforestation is a major concern. 
Table 2. Deuterium excess values of surface and groundwater samples in Sierra de Gador and Campo de Dalias.

\begin{tabular}{lcl}
\hline Site & d-excess value & Reference \\
\hline Surface and groundwater sampled in 1999 and 2000 & $10.23^{*}$ & Vandenschrick et al, 2002 \\
Runoff in the Sierra de Gador & $2.0(17)^{* *}$ & \\
& 12.50 & Vandenschrick et al, 2002 \\
Shallow groundwater in the Sierra de Gador & $1.45(11)$ & \\
& 13.79 & Vandenschrick et al, 2002 \\
Deep groundwater in the Campo de Dalias & $1.07(11)$ & \\
& & \\
Deep groundwater on the fringe of the Sierra de & 12.48 & Vallejos et al. 1997 \\
Gador sampled from 1991-1993 & $2.28(17)$ & \\
Borehole 140 & 14.00 & Vallejos et al. 1997 \\
& $1.61(16)$ & Vallejos et al. 1997 \\
Borehole 372 & 12.55 & \\
& $2.29(17)$ & Vallejos et al. 1997 \\
Borehole 567 & 13.60 & Vallejos et al. 1997 \\
& $1.78(18)$ \\
Borehole 737 & 13.16 & \\
Borehole 1137 & $1.91(18)$ & \\
& & \\
\hline
\end{tabular}

Vallejos et al., 1997

\section{Conclusion}

It was demonstrated that the deuterium excess of precipitation samples can be used as a parameter to distinguish between Atlantic and Mediterranean origin of individual events. The spatial analysis of $d$-excess values in stations of the GNIP network around the Mediterranean basin allowed us to characterise the precipitation typology of the western Mediterranean. However, the Mediterranean character of precipitation increases with monthly precipitation volume. The d-excess values of the Campo de Dalias aquifer cannot be explained by the weighted mean precipitation. One has to consider the influence of the increasing Mediterranean character of the heavier storms. Moderate storms are therefore underrepresented in the aquifer and it is these storms which could possibly increase recharge through deeper percolation of local runoff on hillslopes.

ALONSO-SARRIA F., LOPEZ-BERMUDEZ F. \& CONESA-GARCIA C. (2002), "Synoptic Conditions Producing Extreme Rainfall Events along the Mediterranean Coast of the Iberian Peninsula», in BULL L.J. \& KIRKBY M.J. (eds.), Dryland Rivers: Hydrology and Geomorphology of Semi-arid Channels, pp. 351-372.

ARAGUAS-ARAGUAS L., FROEHLICH K. \& ROZANSKI K. (2000), «Deuterium and oxygen-18 isotope composition of precipitation and atmospheric moisture», Hydrological Processes, 14, pp.1341-1355.

BAJJALI W., CLARK I. D. \& FRITZ P. (1997), «The artesian thermal ground-waters of northern Jordan: insights into their recharge history and age», Journal of hydrology, 192, pp. 355-382. precipitation in the Western Mediterranean region et three different time scales», Geophysical research letters, 28, 7, pp. 1215-1218. 


$$
\text { areas }
$$

33 MALIKI M.A., KRIMISSA M., MICHELOT J.L. \& ZOUARI K. (2000), «Relationship between shallow and deep aquifers in the Sfax basin (Tunisia)», C.R. Acad. Sci. Paris, Sciences de la Terre et des Planètes, 331, pp. 1-6.

, GUNAY G., HOTZL H. REICHERT B. SOLOMON D.K., \& TEZCAN L. (1999), «Separation of ground-water-flow components in a karstified aquifer using environmental tracers», Applied Geochemistry, 14, pp. 1001-1014.

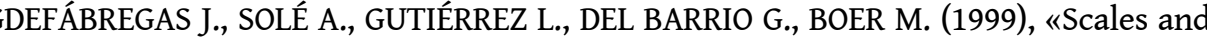
processes of water and sediment redistribution in drylands: results from Rambla Honda field site in Southeast Spain», Earth-Science Reviews, 48, pp. 39-70. 
the Campo de Dalias (Almeria)», in PULIDO-BOSCH A. (ed.), Some Spanish Karstic Aquifers, University of Granada, pp 159-181.

SUMMER G., HOMAR V. \& RAMIS C. (2000), «Precipitation seasonality in eastern and southern coastal spain», International journal of climatology, 21, pp. 219-247.

TANTAWI M.A., EL-SAYED E. \& AWAD M.A. (1998), «Hydrochemical and stable isotope study of groundwater in the Saint Catherine-Wadi Feiran area, South Sinai, Egypt», Journal of African Earth Sciences, 26, pp. 277-284.

TOUT D. (1990), «The horticulture industry of Almeria Province, Spain», The Geographical Journal, 156, 304-312.

VALLEJOS A., PULIDO-BOSCH A., MARTIN-ROSALES W. \& CALCACHE M.L. (1997), "Contribution of environmental isotopes to the understanding of complex hydrologic systems. A case of study: Sierra de Gador, S.E. Spain», Earth Surface Processes and Landforms, 22, pp. 1157-1168.

41 VANDENSCHRICK G. (2002), L'excès en deutérium comme moyen d'étude de l'origine des paléoprécipitations. Exemples espagnols et groenlandais, unpublished $\mathrm{PhD}$ thesis, Université catholique de Louvain, Belgium.

VANDENSCHRICK G., VAN WESEMAEL B., FROT E., PULIDO-BOSCH A., MOLINA L., STIEVENARD M. \& SOUCHEZ R. (2002), «Using stable isotope analysis $\left(\delta \mathrm{D}-\delta^{18} \mathrm{O}\right)$ to characterise the regional hydrology of the Sierra de Gador S.-E Spain», Journal of hydrology, (in press). J. (1998), «Collection and storage of runoff from hillslopes in a semi-arid environment: Geomorphic and hydrologic aspects of the aljibe system in Almeria Province Spain», Journal of Arid environment, 40, pp. 1-14.

44 YAIR A. \& LAVEE H. (1985), "Runoff generation in arid and semi-arid zones», in ANDERSON M.G. \& BURT T.P. (eds.), Hydrological Forecasting, Jon Wiley and sons, pp. $183-220$.

\section{ABSTRACTS}

This paper demonstrates the use of the deuterium excess parameter to distinguish between origin of precipitation in the Mediterranean basin. Isotope signatures in precipitation from the GNIP network around the Mediterranean basin and literature data are combined with isotopic data from aquifers in south east Spain to explain the typology of the precipitation events dominating recharge. Although precipitation from Atlantic origin (d-excess $=10 \%$ ) occurs more frequently in the western Mediterranean basin, the quantities in each event are generally moderate to low. Important rainfall events generally have Mediterranean origin ( $\mathrm{d}$-excess $=15 \%$ ). The total precipitation in Gibraltar is a mixture between precipitation from both origins (dexcess in Gibraltar $=12.39 \%$ ). . However, with increasing volume of the storms the Mediterranean character dominates. These heavier storms contribute mainly to recharge, as illustrated by the $\mathrm{d}$ excess of $13.8 \%$ in deep groundwater of the Campo de Dalias (Almeria province). One of the 
challenges to meet ever-growing water demands is to increase recharge from events with a low return period yielding intermediate quantities per event, but forming the bulk of the annual precipitation.

Cet article met en avant le paramètre «excès en deutérium» dans la détermination de l'origine des précipitations dans le bassin méditerranéen. Afin d'expliquer la nature des précipitations qui dominent la recharge de l'aquifère, nous avons combiné les signatures isotopiques fournies par le réseau GNIP avec les données de la littérature ainsi que des teneurs isotopiques provenant d'aquifères du sud-est de l'Espagne. Dans la partie ouest du bassin méditerranéen les précipitations provenant de l'Atlantique (excès en $\mathrm{d} .=10 \%$ ) sont fréquentes mais celles d'origine méditerranéenne (excès en $\mathrm{d} .=15 \%$ ) possèdent des volumes mensuels plus importants. La teneur isotopique des précipitations totales à Gibraltar indique une origine géographique mixte des pluies (excès en d. à Gibraltar = 12,39\%). Plus les volumes mensuels de pluie sont élevés plus le caractère méditerranéen s'affirme. Ces fortes précipitations contribuent principalement à la recharge, en effet l'excès en deutérium des nappes profondes du Campo de Dalias (province d'Almeria) correspond à 13,8 \%. L'un des défis rencontrés pour satisfaire la demande croissante d'eau consiste à accroître la recharge à partir de précipitations présentant une faible période de retour et produisant des quantités moyennes de pluie par événement, mais qui constituent la majeure partie des précipitations annuelles.

\section{INDEX}

Mots-clés: isotopes stables de l'eau, recharge des nappes phréatiques, origine des précipitations, Espagne

Keywords: water stable isotopes, groundwater recharge, precipitation origin, Spain

\section{AUTHORS}

\section{ELISABETH FROT}

Département de Géographie, Université catholique de Louvain, Belgium

\section{BAS VAN WESEMAEL}

Département de Géographie, Université catholique de Louvain, Belgium

\section{GRÉGOIRE VANDENSCHRICK}

Département de Géographie, Université catholique de Louvain, Belgium

\section{ROLAND SOUCHEZ}

Département des Sciences de la Terre et de l'Environnement, Université Libre de Bruxelles, Belgium

\section{ALBERT SOLÉ BENET}

Estacion Experimental de Zonas Aridas, CSIC, Almeria, Spain 